
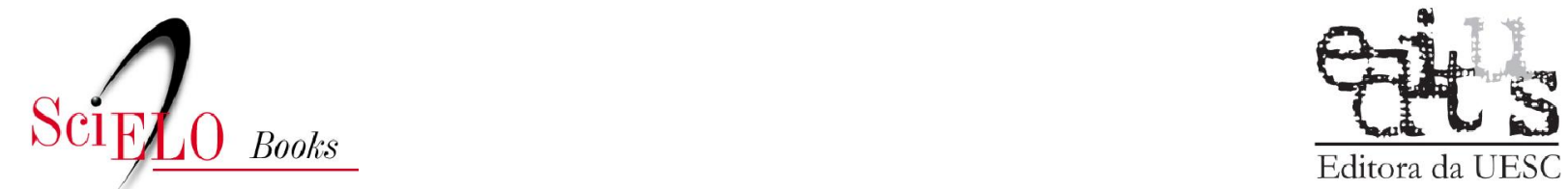

\title{
9 Modelos de recuperação ambiental
}

\author{
Danilo Sette de Almeida
}

SciELO Books / SciELO Livros / SciELO Libros

ALMEIDA, DS. Modelos de recuperação ambiental. In: Recuperação ambiental da Mata Atlântica [online].3rd ed. rev. and enl. Ilhéus, BA: Editus, 2016, pp. 100-137. ISBN 978-85-7455-440-2.

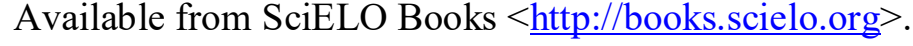

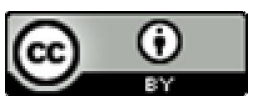

All the contents of this work, except where otherwise noted, is licensed under a Creative Commons Attribution $\underline{4.0 \text { International license. }}$

Todo o conteúdo deste trabalho, exceto quando houver ressalva, é publicado sob a licença Creative Commons Atribição 4.0.

Todo el contenido de esta obra, excepto donde se indique lo contrario, está bajo licencia de la licencia Creative Commons Reconocimento 4.0. 


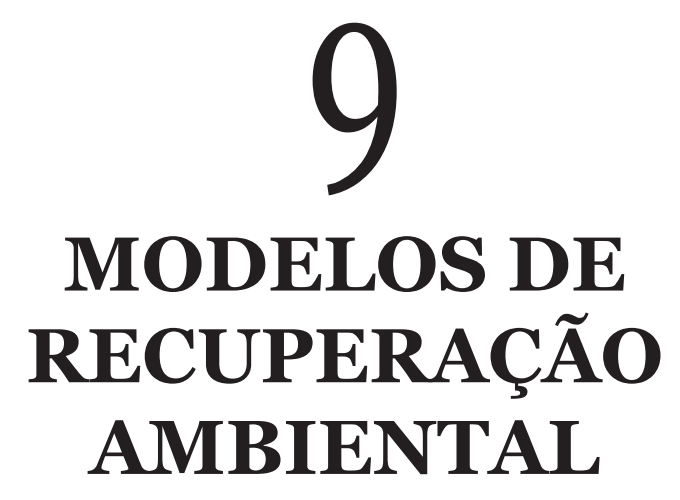


Q uando pensamos em recuperar ambientalmente uma área, devemos sempre associar nosso planejamento aos processos naturais de sucessão, além de considerar sempre as interferencias externas presentes nos ecossistemas que fazem com que as sequências sucessionais possam tomar diferentes caminhos. $\mathrm{Na}$ verdade, reproduzimos o processo natural, e se temos bom conhecimento deste, vamos acelerar as mudanças das comunidades visando atingir o clímax, mesmo que este originalmente não seja alcançado. Entende-se, hoje, por recuperação ambiental, um termo mais amplo, mais holístico, que envolve recuperação do meio biótico e do meio físico. Conforme citado por Reis et al. (1999), devemos promover a sucessão de todos os elementos (solo, microflora, flora e fauna), o que fará que a área ganhe nova resiliência (capacidade de voltar a um estado de equilíbrio).

\subsection{Alguns modelos de recuperação ambiental}

Para o planejamento e desenho de projetos de recuperação ambiental de áreas degradadas, é necessário pensar globalmente em termos do ecossistema a ser recuperado, sua estrutura atual e necessidade de reestruturação física (baseado nos conhecimentos obtidos nos diagnósticos) e conhecimento da sucessão, visando acelerar a recomposição de vegetação natural da área. Temos sempre de ter em mente nosso principal objetivo, isto é, recuperar a floresta o mais próximo possível da original, o que obteremos somente através do conhecimento dos vários compartimentos e suas inter e intrarrelações. Assim, poderemos compreender os processos sucessionais, permitindo-nos traçar estratégias de recuperação eficazes que, realmente, acelerem a reabilitação de áreas degradadas.

Hoje em dia, com o conhecimento existente sobre ecossistemas naturais, como no caso da Mata Atlântica, consideramos que não é admissível o uso de espécies exóticas (de regiões, ecossistemas / ambientes diferentes daquelas que estão sendo recuperadas) em plantios de recuperação ambiental. Mesmo em plantios homogêneos necessários para áreas com nível maior de degradação, pode ser utilizada a técnica de plantios mais homogêneos com espécies pioneiras regionais que possuem ótima relação com a fauna silvestre, atraindo este componente rapidamente para a área em recuperação. 
Observa-se, no Brasil, uma tendência à elaboração de "receitas" generalizadas, este procedimento generalista é, muitas vezes, a causa do fracasso de muitos projetos de recuperação ambiental. O tratamento de reestruturação física da área e a seleção das espécies adequadas a seu ambiente específico, densidade de plantio ou semeio (baseados em levantamentos florísticos e estruturais), tipo de propágulo (semente, estacas ou mudas), cronograma de implantação, enfim todo projeto deve ser desenvolvido voltado, especificamente, para a área em questão.

No caso de desenvolvimento de modelos para florestas tropicais, como a floresta atlântica que estamos trabalhando, a base de conhecimento sobre a biodiversidade é fundamental para o desenvolvimento de modelos de manejo e recuperação, de preferência quando nosso objetivo é recompor a biodiversidade original da região. Frisamos a necessidade do planejador de possuir uma visão holística, indispensável, considerando que estamos trabalhando com um ecossistema complexo, como a floresta atlântica, que possui muitas interações entre os elementos bióticos e abióticos.

O desenho de modelos de recuperação de áreas degradadas deve contemplar e se adequar a cada situação de degradação presente na área. Com base em informações obtidas no diagnóstico (meio físico, biótico, presença de regeneração natural, proximidade de fragmentos florestais e fatores limitantes) e informações sobre sucessão natural do ecossistema em questão, é definido o melhor método ou combinação de métodos específicos a serem utilizados para cada situação, ou conjunto de situações apresentado. Geralmente, quanto mais degradada se apresenta uma área, devemos utilizar uma maior densidade de espécies pioneiras, nunca esquecendo que espécies pioneiras são sempre especialistas em determinados ambientes, apesar de possuírem grande plasticidade em determinados ambientes, apenas algumas espécies pioneiras devem ser utilizadas (exemplo: matas ciliares, brejos, topo de morros).

A definição do modelo de restauração para uma determinada área degradada depende de fatores como: grau de degradação e histórico da área, disponibilidade de sementes e mudas, solo, clima, máquinas e implementos agrícolas e recursos financeiros disponíveis (FERRETTI, 2002).

A seguir, seguem dicas gerais para escolha e desenho de modelos de recuperação ambiental: 
1. O Diagnóstico da área a ser recuperada e entorno deve ser a principal referência para definição das estratégias de recuperação a serem utilizadas. Estudos florísticos e fitossociológicos de remanescentes florestais presentes, em áreas próximas ou vizinhas à área a ser recuperada, são as melhores referências para definição de espécies a serem utilizadas, espaçamento de plantio, proporções entre grupos ecológicos etc.

2. Utilizar somente espécies nativas da região, tomando como base estudos florísticos e fitossociológicos, realizados nas proximidades da área em ambientes similares (encostas, matas ciliares, áreas planas, brejos etc.).

3. É fundamental a utilização de espécies pioneiras, principalmente, se a área se encontrar totalmente sem vegetação. A proporção de espécies pioneiras deve ser definida em função do grau de degradação da área a ser recuperada.

4. A experiência prática tem mostrado que, quanto maior diversidade de espécies nativas utilizarmos na fase inicial dos plantios, melhores serão os resultados em longo prazo. Portanto devemos utilizar o maior número possível de espécies, sempre tomando como base os estudos florísticos e fitossociológicos realizados.

5. Em florestas tropicais geralmente mais de $80 \%$ das espécies têm suas sementes dispersas por animais. Portanto devemos verificar na listagem de espécies que iremos utilizar a proporção de espécies zoocóricas presentes. Devemos lembrar de que médios e grandes mamíferos têm seus alimentos geralmente em espécies secundárias tardias e clímax, e pequenas aves e morcegos têm seus alimentos, em especial, produzidos por espécies pioneiras.

Dentro dos objetivos da recuperação apresentamos, a seguir, alguns modelos/estratégias de recuperação, baseados nos conceitos de restauração ecológica, que podem ser utilizados em diferentes situações apresentadas. Em muitas áreas, a melhor estratégia pode ser uma combinação do uso de vários modelos de recuperação. 


\subsubsection{Condução da regeneração natural}

Em função do potencial de regeneração apresentado por uma área, este é um método que pode ser eficaz e se tornar uma boa estratégia a ser utilizada, em áreas com menor grau de perturbação, onde temos uma boa cobertura florestal e possibilidade de migração de propágulos, principalmente em função do custo de implantação. A estratégia de contemplar a regeneração natural consiste em favorecer a recuperação natural de uma área após distúrbio, funciona bem para áreas recém-desmatadas e que possuem meios de regeneração natural, ou seja, banco de sementes, banco de plântulas, chuva de sementes e rebrota de cepas.

Em casos de áreas desmatadas há mais tempo, é interessante uma análise mais minuciosa da regeneração. A proximidade da área degradada de fragmentos florestais pode também acelerar a regeneração natural através da migração de propágulos (atuação do processo denominado de chuvas de sementes).

O uso deste modelo pode estar combinado à adoção de algumas medidas complementares como o cercamento da área (necessário para evitar a entrada de animais domésticos), controle de espécies invasoras (espécies como gramíneas, ciperáceas e outras invasoras podem inviabilizar o sucesso deste método), coroamento das mudas presentes (limpeza ao redor das mudas arbóreas presentes), construção de aceiros (necessário para evitar que o fogo, proveniente de áreas vizinhas, avance sobre a área), colocação de poleiros artificiais (boa prática, pois pássaros, ao pousarem para descansar, trazem sementes de áreas vizinhas - ficam presas ao bico ou através das fezes), plantio de mudas arbóreas nas clareiras (se a área apresentar boa regeneração de uma maneira geral, porém com algumas áreas internas - clareiras - sem regeneração), o plantio de espécies pioneiras nas áreas de clareiras pode uniformizar mais a regeneração da área em questão.

A rebrota de cepas pode representar, em alguns casos, a forma mais importante de regeneração da vegetação florestal, o potencial de rebrota de espécies florestais e arbustivas destas áreas, especialmente em áreas que sofreram de queimadas, tem grande importância na regeneração e recobrimento da área perturbada. Em florestas tropicais, várias espécies se destacam pelo potencial de rebrota de cepas, regenerando bem após certos distúrbios. 
Este método de recuperação ambiental apresenta menor custo de implantação em relação a outros e, com ajustes, pode apresentar bons resultados.

\subsubsection{Plantio de mudas}

Dentre os métodos de recuperação de áreas degradadas, o plantio de mudas é o mais usual. O objetivo principal é acelerar o processo de sucessão natural, proteger rapidamente o solo contra a erosão e garantir o aceleramento e sucesso da recuperação. Nas áreas de domínio da floresta atlântica, em que temos geralmente boas condições climáticas (boas precipitações e chuvas bem distribuídas) é um método muito indicado, por isso um dos mais utilizados. A grande vantagem deste método é termos o controle da densidade de plantio, que deverá ser preferencialmente próxima da original - no mesmo ambiente e estágio sucessional, como também controle da composição florística inicial, que, se baseada em estudos técnicos florísticos e fitossociológicos, vai ter composição próxima da floresta existente naquele ecossistema e ambiente específico. Este método de recuperação é de fácil operacionalização e de custo reduzido em áreas de fácil acesso. Conforme a situação, fase de degradação e

FOTO 10 - Muda plantada de gurindiba (Trema micranta Triana), município de Eunápolis - estado da Bahia

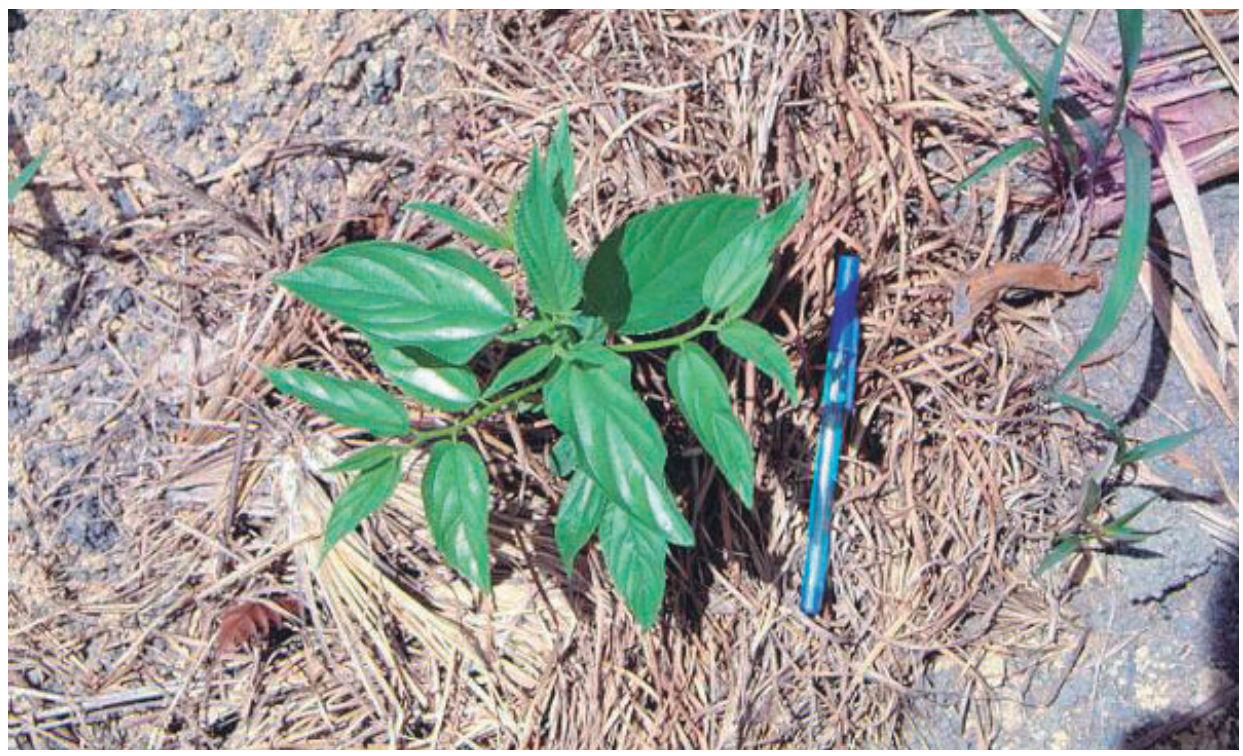


perturbação da área degradada, o plantio de mudas pode contemplar espécies herbáceas, arbustivas ou arbóreas, visando fornecer uma cobertura imediata e proteger melhor o solo.

Este método também é utilizado para os chamados plantios de enriquecimento, onde vamos introduzir espécies dos grupos secundárias tardias e clímax em áreas nas quais já existe alguma regeneração florestal e, consequentemente, condições para o desenvolvimento de espécies destes grupos - principalmente sombra e solo florestal já em formação.

Quando não temos um viveiro florestal próximo à área a ser restaurada, uma alternativa a ser considerada é o plantio de mudas coletadas no campo, em áreas vizinhas ou ambientes similares. Além da economia da produção da muda, ganhamos tempo (para formação das mudas). Esta técnica pode dar resultados satisfatórios em função das espécies a serem trabalhadas. Várias espécies arbóreas podem ser plantadas com a utilização deste método, porém é necessário considerar o impacto na regeneração natural das áreas de origem (retirada) das mudas, assim como ter cuidados para não danificar o sistema radicular na operação de transplante. Este método somente deve ser utilizado onde temos extrema dificuldade de obter material de propagação (sementes e mudas), sendo aplicado principalmente em plantios de enriquecimento, em ambientes sombrios. No caso de áreas abertas, as mudas teriam de passar por um período de aclimatação, antes de serem levadas para o plantio no campo. Silva Filho (1988) cita que algumas espécies apresentam grandes produções de sementes e abundante regeneração natural, este excesso de mudas produzidas pode ser utilizado em outras áreas, pobres em materiais de propagação. A grande vantagem do transplante é a redução do custo de produção das mudas e adaptação às condições mesológicas da região. Este método deve ser sempre aplicado, quando o solo estiver úmido, de preferência na estação chuvosa da região.

A recuperação de matas ciliares, hoje bastante com ênfase em função do pagamento de serviços ambientais, especialmente na "produção de água", tem sido realizada principalmente através do plantio de mudas nativas autóctones do ambiente de florestas ripárias (matas ciliares). A realização prévia de estudos florísticos e fitossociológicos, em fragmentos florestais de matas ciliares na mesma bacia, no lugar em que se pretende conduzir os trabalhos de 
FOTO 11 - Plantio de mudas na recuperação de matas ciliares, restauração das matas ciliares do Rio da Dona, Santo Antônio de Jesus, Bahia

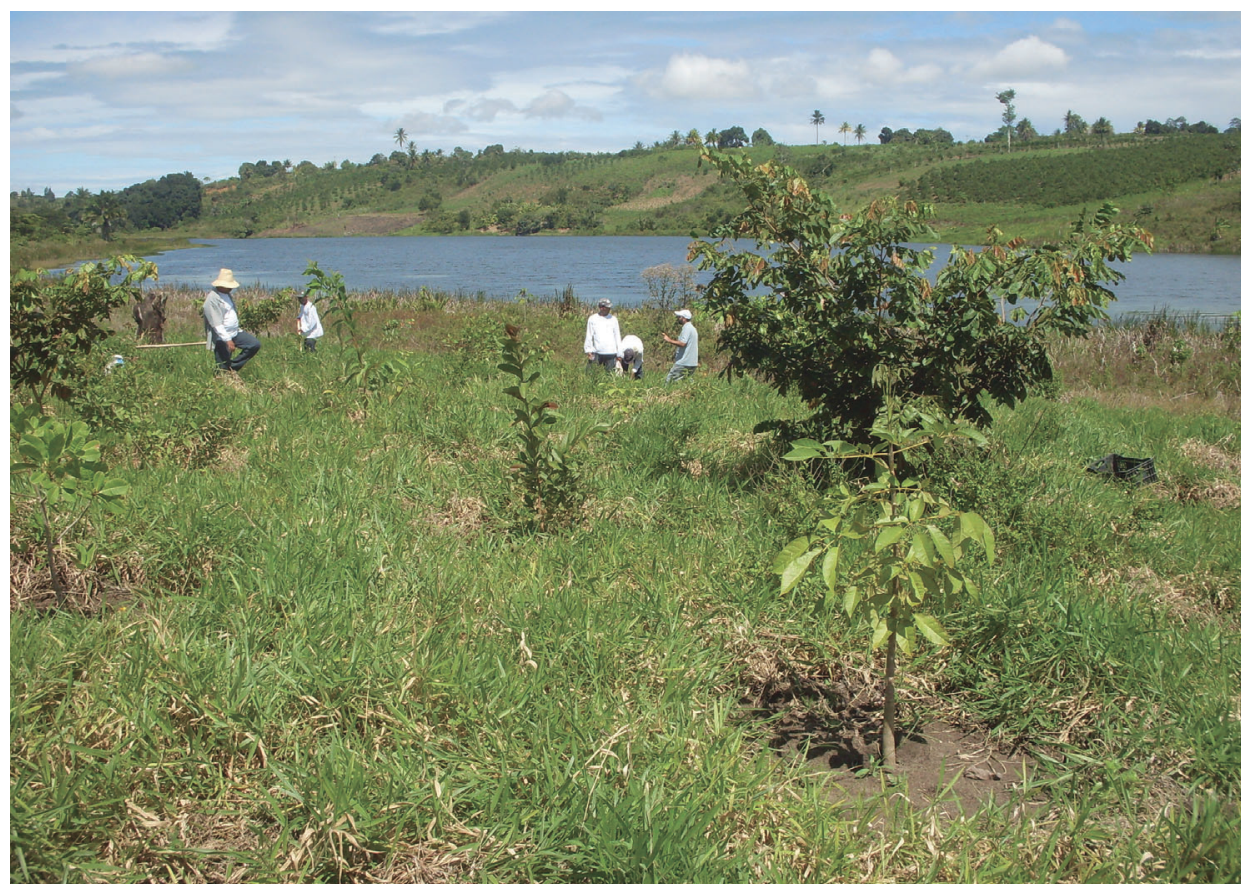

restauração ecológica é um requisito básico quando se pretende restaurar a floresta mais próxima possível da original. A foto 11 mostra trabalho de restauração das matas ciliares, realizado no município de Santo Antônio de Jesus, no lago da barragem do Rio da Dona, responsável pelo abastecimento de água da cidade.

\subsubsection{Recuperação com espécies pioneiras}

O plantio de recuperação ambiental com o uso de 100\% de espécies pioneiras é um bom modelo para ser aplicado em algumas situações específicas, de preferência em áreas vizinhas ou bem próximas a algum fragmento florestal, onde provavelmente os ajustes naturais sejam suficientes para promover o enriquecimento natural da área, reduzindo custos de plantios de enriquecimento complementares. É recomendada, também, quando a área se apresenta muito degradada de tal forma que a regeneração natural não acontece, e espécies secundárias e clímax não se estabeleceriam neste ambiente (ambientes de baixa resiliência). Este modelo tem como 
vantagem o recobrimento de vegetação rápido do local em restauração, proporcionando rápida proteção ao solo. Com relação aos custos, apresenta menor custo de manutenção, pois, devido ao rápido crescimento das espécies e sombreamento, a vegetação competidora sai logo do sistema, porém pode ter custos adicionais se forem previstos e necessários plantios de enriquecimento em longo prazo.

A utilização de espécies florestais de rápido crescimento, principalmente as pioneiras, é mencionada por vários autores, que citam este método como aquele que permite uma melhor aproximação das condições existentes do ecossistema original (para áreas antes cobertas por florestas, como a Atlântica, por exemplo). Uma grande vantagem da utilização de espécies pioneiras é sua rusticidade, proporcionando redução de gastos nas etapas de implantação e manutenção, devido ao rápido recobrimento do solo.

Para ilustrar, damos um exemplo - descrição superficial de um modelo de reabilitação (com uso de espécies pioneiras), que pode ser aplicado em áreas degradadas, utilizando somente espécies pioneiras autóctones com a finalidade de obter rápido recobrimento do solo e acelerar o processo de sucessão natural. Possibilita enriquecimentos futuros - via sementes ou mudas - de espécies pertencentes a outros grupos ecológicos, após a área desenvolver ambientes propícios para o enriquecimento.

Este modelo pode ser conciliado com outros métodos e técnicas como o "ilhas de biodiversidade", "uso de serapilheira", "ampliação ecológica", visando garantir sua sustentabilidade das restaurações da área em longo prazo.

\subsubsection{Formação de ilhas de diversidade (Nucleação)}

Este modelo de restauração, que pode ser utilizado, é baseado em diversos estudos sobre recuperação de áreas degradadas, mostrando que a tendência natural do processo sucessional é não recobrir áreas de maneira uniforme (GRIFFITH et al., 1994), a natureza utiliza "ilhas de diversidade". Estas áreas de disseminação de propágulos são responsáveis pelo aumento de diversidade de uma área em processo de recuperação. Este processo natural pode ser replicado em modelos de recuperação, com formação de ilhas de vegetação com espécies chaves para atração de fauna (polinizadores e dispersores). 
Autores, como Reis et al. (1999), citam os chamados "centros de alta diversidade", áreas onde deveriam ser incluídas as formas de vida das espécies vegetais e suas adaptações aos estágios sucessionais (pioneiras, oportunistas, climácicas, ervas, arbustos, árvores, lianas e epífitas), além de considerar as adaptações aos processos de polinização e dispersão (anemocórica, zoocórica e outros) e de fenofases (principalmente floração e frutificação). No planejamento destas "ilhas de diversidade", áreas são onde intervimos de maneira mais intensa no processo de recuperação, é importante considerarmos também aspectos fitossociológicos (densidades de plantio previamente planejado), baseados em estudos fitossociológicos e de localização (devem ser localizadas estrategicamente no núcleo ou parte central da área, ou na parte mais elevada da área que está sendo recuperada, visando destacar a eficiência na dispersão de propágulos e enriquecimento da diversidade das áreas vizinhas).

Apesar de ser um modelo de recuperação de baixo custo, a recuperação ambiental, a partir de ilhas de vegetação, tende a ser um processo lento, variando em função do número e tamanho das ilhas, sendo recomendada a utilização de espécies atrativas da fauna silvestre (MARTINS, 2001).

O modelo misto entre ilhas (com espécies não pioneiras) e plantio de espécies pioneiras, na área total, também pode ser uma boa estratégia, conforme citado por Kageyama e Gandara (2000). Esta estratégia vai promover o rápido recobrimento do solo, diminuindo o processo de erosão do solo, porém a diversidade de espécies iniciais do plantio é baixa. Autores, como Galvão e Medeiros (2002), recomendam que este modelo seja utilizado para áreas de no mínimo 20 hectares e, neste caso, tenhamos um núcleo de no mínimo 4 hectares. Segundo estes autores, a grande vantagem deste modelo é redução de custos.

Entre as estratégias de nucleação que podem ser utilizadas, segundo Martins (2012), podemos destacar a transposição da serapilheira, do banco de sementes, galhadas, manejo da regeneração natural, resgate de plântulas e a semeadura direta com alta diversidade.

\subsubsection{Modelo sucessional - plantio em linhas alternadas}

O plantio em linhas alternadas é uma boa solução para facilitar o lado operacional de implantação, por isso é o modelo mais 
comumente aplicado em grandes áreas, principalmente em plantios mecanizados. As linhas alternadas facilitam todo trabalho de preparação e embalagem das mudas no viveiro florestal, assim como a parte operacional de plantio de campo, onde os trabalhadores facilmente entenderão o procedimento de plantio. Algumas empresas se utilizam de caixas marcadas ou de diferentes colorações para diferenciar as caixas com espécies pioneiras e de outros grupos. Normalmente, planta-se uma linha de espécies pioneiras (deverão ser utilizadas, nesta linha, todas pioneiras específicas para o ambiente que estamos trabalhando), e outra linha com espécies não pioneiras (representando 50\% das mudas plantadas) (FIGURA 2). Este tipo de plantio facilita bem os aspectos operacionais de implantação do plantio de restauração, separando caixas/contentores de mudas pioneiras e de outros grupos de diversidade.

FIGURA 2 - Esquema de modelo de linhas alternadas, onde " $X$ " representa espécies pioneiras e "O" representa espécies secundárias iniciais, tardias e clímax

\begin{tabular}{|ccccccccccccc|}
$x$ & & $x$ & & $x$ & & $x$ & & $x$ & & $x$ & \\
$x$ & 0 & & 0 & & 0 & & 0 & & 0 & & 0 \\
$x$ & 0 & $x$ & 0 & $x$ & & $x$ & & $x$ & & $x$ & \\
$x$ & & $x$ & & $x$ & & $x$ & & $x$ & & $x$ & \\
\hline
\end{tabular}

Neste modelo de utilização de linhas alternadas, outro item, que deve ser incorporado na seleção de espécies, é a classificação com base na forma da copa, assim devemos utilizar nas linhas destinadas ao plantio de espécies pioneiras, sempre com espécies pioneiras possuidoras de copa larga, pois esta estratégia vai proporcionar o fechamento mais rápido do dossel que está sendo formado na restauração ecológica e, consequentemente, formar sombra e, como resultado, eliminar mais rapidamente a vegetação competidora rasteira (em especial gramíneas) que existia na área a ser restaurada. Esta medida tem importância também na redução do custo financeiro da restauração ecológica, pois as plantas, normalmente competidoras, vão desaparecer mais rápido do ecossistema que ganha mais rapidamente forma e característica florestal. A FIGURA 3 mostra outra alternativa de modelo com uso de maior densidade de espécies pioneiras $(75 \%$ 
FIGURA 3 - Esquema de modelo de linhas alternadas, onde " $X$ " representa espécies pioneiras, que neste modelo representam $75 \%$ das espécies utilizadas e "O" representa espécies secundárias iniciais, tardias e clímax ( $25 \%$ das espécies utilizadas)

\begin{tabular}{|lllllllllllllll}
\hline & & $x$ & & $x$ & & $x$ & & $x$ & & $x$ & \\
$x$ & & & $x$ & & $x$ & & $x$ & & $x$ & & $x$ & \\
& $x$ & & 0 & & $x$ & & 0 & & $x$ & & 0 \\
& & & & & & & & & & & & & &
\end{tabular}

das espécies plantadas) contra 25\% de espécies de outros grupos que vão conferir diversidade ao plantio realizado (secundárias iniciais, tardias e clímax).

Para a aplicação de fatores relacionados à forma e crescimento horizontal da copa, no modelo de linhas alternadas com $75 \%$ de espécies pioneiras, a classificação com base na forma da copa também tem grande aplicabilidade. Nas linhas, onde existem somente os "X" (linhas de 100\% pioneiras), devemos utilizar sempre espécies pioneiras de copa larga, facilitando o fechamento mais rápido do dossel e a redução do custo de manutenção.

Do ponto de vista operacional, neste modelo, podemos utilizar diferentes tipos de tubetes ou embalagens, ou mesmo caixas demarcadas, para diferenciar, na prática, as espécies pioneiras e não pioneiras. Funcionalmente, uma estratégia muito utilizada é das mudas virem do viveiro já preparadas e misturadas em caixas de plantio, ou caixas somente de pioneiras, ou caixas já misturadas pioneiras, e outros grupos nas proporções previstas no modelo a ser utilizado, esta prática facilita muito a operação de plantio de mudas no campo. As espécies a serem utilizadas e as respectivas quantidades de mudas de cada espécie deverão ser definidas em função dos estudos florísticos e fitossociológicos, realizados para o local em recuperação.

Este modelo se mostra bem prático e flexível, pois permite a combinação de espécies pioneiras e não pioneiras em diferentes proporções. Por exemplo, em uma área mais degradada, podemos utilizar 75\% de espécies pioneiras, isto é, uma linha de espécies pioneiras e outra linha, alternando espécies pioneiras e não pioneiras (FIGURA 2).

O espaçamento a ser utilizado vai variar em função dos estudos fitossociológicos, realizados na região (áreas ainda com cobertura 
florestal que possuam características similares a área a ser recuperada), assim como o tipo e exposição do solo, declividade (relevo), presença de plantas invasoras e disponibilidade de recursos financeiros e de equipamentos (maquinários).

Para melhor desempenho deste modelo sugerimos que os plantios não sejam muito alinhados como reflorestamentos comerciais. Eles devem seguir somente uma linha de referência sem compasso exato de espaçamento, dentro da mesma "linha", da mesma maneira podemos desalinhar as covas, buscando maior semelhança com a regeneração natural e com o que observamos nas florestas nativas.

O plantio, em uma só etapa, pode reduzir em muito o custo da recuperação. É um método indicado para áreas que apresentam

FOTO 12 - Sequência de recuperação ambiental de uma área por plantio de mudas em linhas alternadas, onde primeira foto com seis meses após plantio, segunda com 5 anos após plantio e terceira foto 10 anos após plantio, quando a altura médio ultrapassou 10 metros. Santa Cruz Cabrália, Bahia
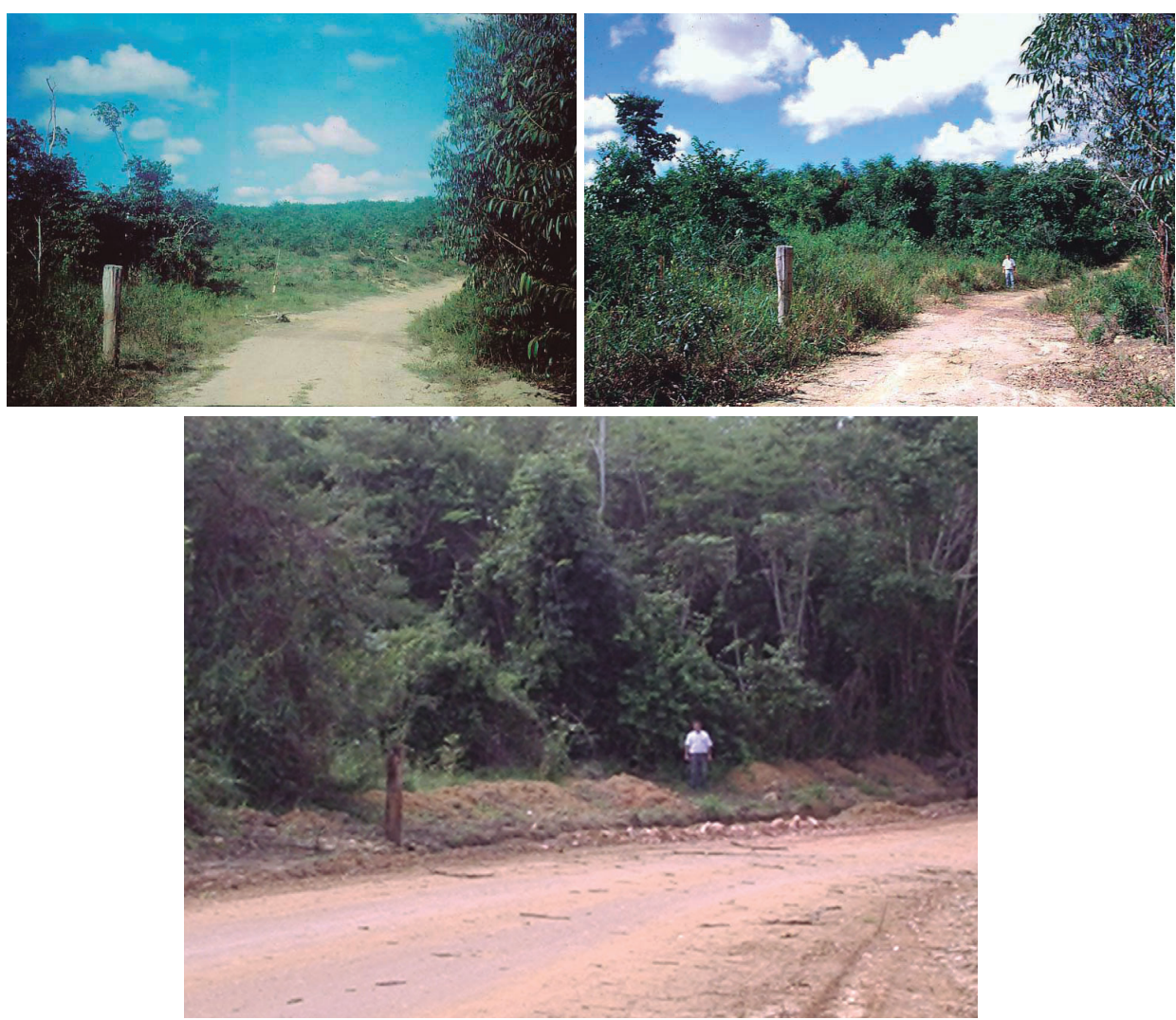
condições favoráveis para um rápido desenvolvimento das mudas e estabilização e sustentabilidade do plantio.

A implantação destes modelos no campo, considerando as experiências do extremo sul da Bahia (ALMEIDA, 1994), tem demonstrado que, nos plantios, em linhas alternadas, realizados em áreas abertas, a mortalidade tem sido bem maior no grupo de espécies não pioneiras que na linha de espécies pioneiras. Portanto este modelo tem esta grande vantagem de poder adequar, conforme estado de degradação apresentado na área, a exata proporção de espécies pioneiras e não pioneiras.

\subsubsection{Modelo sucessional - plantios em módulos}

O modelo sucessional separa as espécies por grupos ecofisiológicos. Neste modelo de módulos, utiliza-se uma planta na parte central (secundária tardia ou clímax), rodeada por quatro espécies pioneiras (espécies sombreadoras). Os módulos são implantados dispostos por toda área que está sendo recuperada. É um modelo mais aplicável em áreas menores, para áreas maiores é mais comumente utilizado o plantio em linhas alternadas.

\subsubsection{Indução da chuva de sementes}

É um método de custo reduzido que é aplicável em áreas de difícil acesso, onde a aplicação de outros métodos de recuperação seria inviável operacionalmente, em função de transporte de insumos, pessoal etc. Este método é mais aplicado quando temos boa disponibilidade de sementes na região de implantação do projeto e, normalmente, existe algum impedimento ao plantio de mudas.

Pesquisas realizadas, utilizando este método, no estado de São Paulo (ENGEL et al., 2002), mostram que a semeadura direta pode ser viável, principalmente para algumas espécies pioneiras e quando se faz um tratamento prévio na superfície do terreno.

\subsubsection{Plantio inicial de mudas e posterior semeio}

Modelo misto que constitui o plantio inicial de $100 \%$ de espécies pioneiras na área total e, posteriormente (após o plantio gerar condições de sombra e solo para germinação de espécies secundárias), 
a promoção do enriquecimento da área com sementes de espécies secundárias tardias e clímax entre o plantio de espécies pioneiras. As sementes de espécies secundárias tardias e clímax que, geralmente, são sementes grandes e não possuem problemas de dormência, germinando bem nas condições de campo. É um método de baixo custo (pois implica somente no plantio de pioneiras) e, na segunda fase, apenas semeio de espécies não pioneiras.

Este modelo está sendo testado no extremo sul da Bahia (VERACEL, 2005), onde estas espécies germinam bem, sobretudo no ambiente criado após o plantio de espécies pioneiras (após um ano do plantio), no qual temos um nível de sombreamento e não existe mais concorrência com gramíneas. É um modelo que funciona bem na região sul e extremo sul da Bahia, onde temos chuvas bem distribuídas durante todo ano e não temos déficit hídrico.

\subsubsection{Plantio de estacas diretamente no campo}

A técnica de plantio de estacas pode ser utilizada com sucesso para determinadas espécies florestais e arbustivas. As limitações encontram-se no fato de que são poucas espécies a aceitar este tipo de propagação e necessidade de chuva constante, no período inicial do processo ou irrigação até pegamento das estacas e seu estabelecimento, ou exige irrigação intensa no período pós-plantio.

Várias espécies florestais nativas da floresta atlântica mostram bons resultados neste tipo de plantio, podemos citar o cedro (Cedrella fissilis e Cedrella odorata) e diversas espécies de gameleiras (Ficus spp.).

Técnicas que podem ser utilizadas para melhorar o pegamento das estacas no campo são: utilização de hormônios aceleradores de enraizamento, utilização de gel ou solução hidratante junto à cova de plantio.

\subsubsection{Semeio direto (Muvuca)}

A técnica do semeio direto, apesar de não ser muito utilizada atualmente para espécies florestais, é uma alternativa promissora, em especial se combinada com outros métodos de biológicos, podendo dar bons resultados. Entre as diversas possibilidades de combinação do semeio direto, citamos a conciliação do semeio de 
espécies secundárias tardias e clímax com o plantio de mudas de espécies pioneiras, ou leguminosas. Estas espécies, utilizadas nas etapas iniciais de plantio, criam condições de sombra e de solo especiais, e um ambiente ideal para germinação de algumas espécies, principalmente as secundárias tardias e clímax. Esta combinação de métodos reduz significativamente o custo de recuperação, e o semeio das secundárias deverá ser feito após o crescimento inicial das mudas pioneiras. Esta estratégia pode aumentar substancialmente a diversidade florística da área a ser recuperada.

Mais recentemente, a estratégia de semeio para recuperação de áreas degradadas é a técnica denominada de "muvuca", que consiste na mistura de sementes nativas arbóreas e arbustivas, muitas vezes com sementes agrícolas, para o plantio direto na área escolhida para a recuperação. A mistura das sementes das mais diferentes espécies garante a diversidade de uma floresta, visando estimular a sucessão ecológica natural com o mínimo de intervenção, além de enriquecer e proteger o solo para o efetivo desenvolvimento das espécies nativas. Conforme recomendado (ISA, 2009), em cada cova aberta, deve ser plantada a muvuca de sementes - com árvores, feijões, maracujás, flores etc. - usando de 30 a 100 sementes por metro quadrado.

\subsubsection{Semeadura aérea}

A semeadura aérea ou chuva de sementes é um método biológico, recomendado para ser utilizado, sobretudo em áreas de difícil acesso, onde é inviável operacionalmente a utilização de outros métodos, são utilizadas principalmente espécies pioneiras e em menor intensidade, sementes de espécies secundárias iniciais. Este método foi utilizado com sucesso pela Secretaria de Meio Ambiente, de São Paulo, em 1990, para áreas serranas de floresta atlântica, localizada nas imediações de Cubatão (São Paulo), onde foram adotados os seguintes critérios para seleção de espécies: ocorrência natural na região semeada; distribuição nos estratos herbáceos, arbustivos e arbóreos; alto potencial de dispersão da espécie; alto poder de germinação das sementes; rápido crescimento; alta agressividade na ocupação da área considerada; resistência à poluição atmosférica; disponibilidade de sementes para coleta na região. Porém existem limitações na escolha das espécies a serem utilizadas, em função do tipo de semente (dormência, tamanho e outros fatores). 
Após a realização do semeio aéreo, deve ser feito o monitoramento dos locais semeados, visando acompanhar o desempenho das espécies nas condições de campo. O enriquecimento das capoeiras, formadas na primeira fase, pode ser feito em etapas posteriores, através do plantio manual de espécies arbóreas típicas de estágios mais avançados da sucessão florestal, que exigem certo grau de sombreamento para seu estabelecimento.

As principais limitações da semeadura aérea são: o custo, o grau de compactação e degradação do local a ser recuperado e disponibilidade de sementes compatíveis com o método - tamanho adequado ao semeio e beneficiamento (peletização) e regime de dormência.

Este método pode dar bons resultados em áreas de difícil acesso, com precipitações altas e bem distribuídas e solo pouco compactado na superfície.

\subsubsection{Hidrossemeadura}

Trata-se de uma técnica mecanizada, em que as sementes são lançadas na área a ser recuperada através de jateamento (utilizando uma bomba), em mistura de água, sementes, fertilizantes e outros produtos como agentes cimentantes, com função de aderir a semente à superfície na qual foi aplicada.

Em nosso país, esta técnica tem sido utilizada principalmente na contenção de taludes de estradas e de áreas de mineração, atualmente produz bons efeitos, principalmente quando é combinada com alternativas, como o uso de telas naturais e plantio de mudas.

\subsubsection{Plantio adensado}

É um modelo desenvolvido para ser utilizado em áreas, nas quais temos problemas de invasão com plantas herbáceas (por exemplo, gramíneas invasoras), que competem, grandemente, com as mudas arbóreas plantadas e onde não queremos aplicação de herbicidas. Pina-Rodrigues et al. (1997) aplicaram este método para áreas cobertas com capim colonião (Panicum maximum), utilizando o espaçamento 1,o x 1,o metro (10.000 plantas por hectare), com linhas de espécies pioneiras alternadas com linhas de espécies pioneiras e não pioneiras alternadas, visando obter rápido recobrimento (e 
sombreamento) do solo, reduzindo assim os custos de manutenção. Com o espaçamento reduzido, temos igualmente um rápido recobrimento do solo, controlando a ocorrência das espécies herbáceas invasoras, porém, devido à alta densidade de mudas por hectare, o custo de implantação deste modelo é elevado. Portanto este modelo somente deverá ser utilizado, quando temos sérios problemas com plantas invasoras ou quando temos necessidade de promover uma cobertura rápida, conferindo grande proteção a alguma área degradada (problemas relacionados à grave erosão no solo - voçoroca ou sulco - ou áreas degradadas com solo exposto).

\subsubsection{Plantio de leguminosas}

O plantio de mudas de leguminosas arbóreas, que fixam nitrogênio atmosférico, é uma boa alternativa para áreas em condições de maior degradação ambiental, no lugar em que as camadas superficiais do solo foram retiradas ou fortemente alteradas. Nestas áreas, este grupo de árvores tem efeito bastante positivo, pois, geralmente, possui rápido crescimento e é capaz de melhorar o solo, depositando matéria orgânica. Segundo Dias (1996), o uso de leguminosas arbóreas noduladas e micorrizadas na recuperação de áreas degradadas, tem se mostrado como técnica viável, não só pelo seu baixo custo, como também pela grande capacidade de adaptação e de crescimento destas espécies. A quantidade de N2 fixado ocorre em função do ambiente e dos organismos envolvidos no processo, em espécies de leguminosas florestais relatam-se quantidades de até $500 \mathrm{~kg} / \mathrm{ha} /$ ano (CAMPELLO, 1996).

As leguminosas arbóreas (85\% delas são arbóreas e perenes), em especial aquelas que permitem nódulos, contribuem para recuperação do solo pela deposição de folhedo, aumentando significativamente o teor de matéria orgânica do solo. Também obtemos bons resultados com leguminosas arbustivas. Espécies, como o feijão-bravo do Ceará (Canavalia brasiliense (Jacq.) D.C.), crotalaria (Crotalaria anargyroides), cunhã (Clitoria ternatea L.) e mucuna preta (Mucuna aterrima (P\&T.) Merr.), mostraram bom desenvolvimento em experimentos conduzidos no município de Itaguaí, estado do Rio de Janeiro (VALCARCEL; D’ALTÉRIO, 1988).

Os estudos sobre leguminosas que, inicialmente, eram concentrados somente em espécies exóticas têm-se voltado ultimamente 
também para as espécies nativas, onde já temos espécies e estirpes de rizóbio mais eficientes.

\subsubsection{Recuperação com uso de espécies frutíferas}

O plantio de espécies nativas frutíferas é um modelo bem interessante para proporcionar alimento e atração da fauna silvestre. A formação de pomares de espécies frutíferas para fauna silvestre (não para o homem) permite fornecimento de alimentos para a fauna silvestre. Este modelo pode ser aplicado em áreas próximas a fragmentos florestais, onde vai fomentar a migração de animais da área florestal para a área em restauração, esta migração vai trazer propágulos da floresta original para a área florestal em recuperação. Podem-se usar, neste modelo, espécies frutíferas com capacidade de alimentar vários grupos de fauna (aves, morcegos, roedores etc.), desde que tenhamos conectividade com fragmentos florestais nos quais existam estes grupos de animais.

\subsubsection{Ampliação Ecológica de Fragmentos Florestais}

Tomando como base a situação atual presente e visualizando a necessidade de estabelecimento de novas estratégias de restauração ecológica que promovam uma rápida recuperação da área florestal, restabelecendo o processo sucessional e a sustentabilidade destes fragmentos florestais, está sendo testada e desenvolvida uma nova estratégia de restauração ecológica que toma, como referência básica e ponto de partida, os fragmentos florestais de melhor qualidade ambiental (alto valor de conservação) que ainda mantêm o processo sucessional ativo. A técnica da "Ampliação Ecológica de Fragmentos Florestais" contempla como estratégia a restauração da biodiversidade, partindo das áreas núcleo de alta diversidade ainda existente - fragmentos florestais de floresta primária ou em estágios avançado de regeneração (com alta diversidade de espécies). A promoção da expansão da área do fragmento existente, através de plantios de rápido crescimento nas bordas destes fragmentos florestais, possibilita a redução do efeito de borda e a expansão da área física destes fragmentos florestais, ampliando habitats florestais vizinhos aos fragmentos florestais de alto valor de conservação, permitindo a expansão dos recursos de flora e fauna silvestres e aumentando, consequentemente, a área núcleo destes fragmentos. Esta alternativa surge, dentro 
da situação atual da Mata Atlântica, como uma nova alternativa de promover a restauração ecológica deste bioma e outros ecossistemas fragmentados, tomando como referência e ponto de partida a matriz mais bem conservada (fragmento florestal sustentável).

Esta técnica interfere também no componente faunístico do ecossistema atlântico, pois o aumento da área de fragmentos florestais em bom estado de conservação, onde ainda temos populações animais representativas, é uma das estratégias para propiciar o aumento destas populações, de suma importância como dispersor de sementes do componente florístico (mais de 70\% das espécies da floresta atlântica são zoocóricas, isto é, dependem de animais para sua propagação).

9.1.17 Recuperação ambiental de ecossistemas com invasão de espécies exóticas

Hoje, temos muito presente o problema em relação à situação de áreas naturais, invadidas por espécies exóticas, em muitas áreas florestais e, geralmente, em todos os biomas. A invasão de espécies exóticas pioneiras perturba toda a organização do ecossistema, desde a composição florística e fitossociológica original até relação e interação flora e fauna. Recentemente, tem-se discutido muito, na área de conservação e restauração, a eliminação de espécies exóticas de áreas naturais, principalmente em unidades de conservação. Como exemplo de invasões por espécies exóticas invasoras, citamos muitas restingas no litoral brasileiro. Esta invasão atinge níveis onde se fazem necessárias ações de recuperação ambiental destas áreas invadidas para evitar o total extermínio das espécies nativas daqueles ambientes. Em áreas, nas quais temos invasão de espécies exóticas e descaracterização dos ecossistemas e espécies originais, é importante planejarmos a substituição gradual das espécies exóticas pelas espécies nativas daquele ambiente que está sendo recuperado.

\subsection{Estratégias auxiliares de apoio à recuperação ambiental}

\subsubsection{Utilização de matéria orgânica}

Esta técnica vem sendo utilizada como auxiliar na recuperação de áreas degradadas, sempre conjugada com outros métodos 
produzindo bons efeitos. Conforme a região brasileira, vêm sendo utilizados vários tipos de materiais orgânicos (casca de arroz, bagaço de cana, moinha de carvão, capim) com a intenção de promover o controle da erosão, conservação de água e melhoria da qualidade física e química dos solos. A aplicação da matéria orgânica proporciona uma redução da amplitude da temperatura do solo e aumenta a capacidade de absorção de água, proporcionando também uma recolonização com macro e microrganismos (aumentando a comunidade de microrganismos do solo), além de possibilitar o fornecimento de propágulos de plantas, garantindo o sucesso do processo de recuperação.

Em experimentos conduzidos em áreas de empréstimo, situadas na Ilha da Madeira, município de Itaguaí, estado do Rio de Janeiro, constatou-se que a deposição de matéria orgânica é o ponto chave no processo de "construção" do solo, atuando, sobretudo na melhoria das propriedades físicas do solo (VALCARCEL; D'ALTÉRIO, 1988).

Podemos, então, citar várias consequências decorrentes desta prática:

a. Melhoria da capacidade de retenção e infiltração da água, elevando o nível do lençol freático e aumentando consequentemente a resistência das plantas nos períodos de estiagem.

b. Mecanicamente, melhora a estrutura do solo especialmente quanto à aeração, descompactação e agregação de partículas primárias.

c. Diminuição dos efeitos maléficos da erosão, garantindo imediata proteção do solo. Antes de se decompor, a matéria orgânica atua como anteparo, protegendo o solo do impacto direto das gotas de chuva e atenuando o escoamento superficial.

d. Inoculação de microrganismos, como fungos micorrízicos que ampliam a eficiência do sistema radicular das plantas presentes. Além disto, a matéria orgânica favorece a atividade microbiana por sua capacidade termorreguladora.

e. Aumento do nível de absorção de nutrientes, principalmente equilibrando a absorção de nutrientes solúveis. 


\subsubsection{Uso da manta orgânica florestal (serrapilheira)}

A manta florestal é a camada superficial do solo de uma floresta, constituída por todo material solto depositado na superfície do ecossistema florestal, ou seja: folhas, restos de flores, pequenos galhos em decomposição e repleto de microrganismos, insetos e sementes de plantas herbáceas, arbustivas e arbóreas (IBAMA, 1990). A manta florestal também é designada por serapilheira, manta morta, forest litter, leaf litter. Segundo Molchanov (1971), a manta orgânica é constituída por três camadas: a superior, pouco decomposta; a média, medianamente decomposta; e a inferior, bem decomposta, onde há uma mistura de partículas minerais e matéria orgânica. No perfil do solo, designa-se por "Ao" a manta florestal, alguns autores denominam esta camada de horizonte "O" do solo. A serapilheira representa um verdadeiro banco genético de tudo que ocorre no ambiente natural.

Segundo Martins (2012), esta técnica se baseia na coleta de amostras do solo superficial e sua deposição nas áreas degradadas, além do banco de sementes serão depositados na área degradada nutrientes, associações micorrízicas e matéria orgânica, porém deve ser usada apenas como forma de aproveitamento da camada superficial do solo florestal para os casos em que o licenciamento ambiental autorizou a supressão da vegetação (aproveitamento através do resgate da manta florestal).

Como método de recuperação, a aplicação da manta florestal proporciona uma redução da amplitude da temperatura do solo, aumenta a capacidade de absorção de água, provocando a recolonização de macro e microrganismos, proporcionando um aumento da comunidade de microrganismos do solo, além de possibilitar o fornecimento de propágulos de plantas, garantindo, assim, o sucesso do processo de recuperação. A serapilheira acumulada é um importante reservatório de elementos que pode conferir maior estabilidade ao sistema, além de proteger o solo e atenuar com isso as forças erosivas. Além disso, na manta florestal, podemos encontrar um farto banco de sementes, importante no aceleramento do processo de recuperação. As sementes observadas na manta florestal são principalmente de espécies pioneiras, talvez as mais importantes na reabilitação, por germinarem somente na presença de boa luminosidade (lucíferas), quando existe algum distúrbio. 
A utilização da manta florestal, no processo de reabilitação de áreas degradadas por diversas atividades, pode acelerar em muito o processo de recuperação destas áreas, melhorando as condições químicas, físicas e biológicas do solo, justificando o seu uso. Conforme citado pelo IBAMA (1990), o uso da serapilheira muitas vezes surpreende: tem sido observado, em muitas regiões, que as plantas nascidas dela dão uma cobertura mais rápida e densa ao solo que o uso de espécies exóticas forrageiras.

Dois fatores devem ser levados em conta no planejamento do uso da manta florestal: a disponibilidade de fontes de serapilheira nas proximidades e as características da área a ser recuperada. Segundo o IBAMA (1990), a coleta da manta florestal para a aplicação em recuperação deve ser feita na época das chuvas, nas áreas circunvizinhas e com as mesmas características da área degradada a ser recuperada. Esta coleta deve ser feita com o uso de um rastelo, nunca cavando o solo, juntando o material solto da superfície e colocando-o em sacos plásticos ou balaios. É também recomendado aplicar o material o mais rápido possível após a colheita, e realizar a coleta da serapilheira em áreas alternadas ou em faixas, promovendo o recobrimento da área coletada através de ancinhos, ou outras ferramentas, com material das áreas vizinhas, evitando deixar solo exposto.

Quanto à aplicação da serapilheira, o IBAMA (1990) recomenda que sejam seguidos os seguintes passos:

a. espalhar manualmente o material na superfície, sem incorporação ao solo, na época das chuvas e no mesmo dia;

b. se possível, colocar uma camada de 10,0 cm de espessura, no mínimo;

c. no caso de bancadas, seja nos terraços, seja onde foi feito o plantio de espécies herbáceas nos taludes, a serapilheira deve ser aplicada após o plantio de herbáceas.

Estudos mostram que existe uma relação entre dinâmica de ecossistemas e estações do ano, com deposição de manta florestal. Regra geral, os ecossistemas tropicais, como a floresta atlântica, acumulam mais manta orgânica que as florestas situadas em regiões temperadas. Durante o ano, nos períodos nos quais temos maior temperatura e precipitação, é também maior o acúmulo de 
manta orgânica. Em áreas de floresta atlântica, podemos chegar a mais de 10 toneladas \hectare \ano de matéria orgânica depositada.

O banco de sementes presente na manta florestal vai, se exposto ao solo, gerar plântulas e mudas importantes para restauração da área a ser recuperada.

\subsubsection{Utilização de telas naturais}

O uso de telas confeccionadas, a partir de fibras naturais, tem grande utilidade, principalmente nos trabalhos de recuperação em áreas de declives. As telas naturais possuem a função de reter o solo destas encostas, reduzindo a erosão, estabilizando o ambiente e permitindo a germinação e o estabelecimento da vegetação. É uma estratégia de apoio para ser conciliada com métodos biológicos de restauração, geralmente semeadura a lanço ou hidrossemeadura.

A utilização de telas naturais tem-se intensificado muito na última década, hoje temos várias telas patenteadas no mercado, à base de fibras naturais. Este método derivou-se do uso de sacos de aniagem (abertos sobre o solo ou fechados, contendo terra, adubo e sementes) e telas sintéticas (plástico e metal), métodos antes utilizados em estradas de rodagem e ferrovias, para contenção de voçorocas e em minerações, sobretudo na região montanhosa do estado de Minas Gerais.

Em áreas menores, ainda hoje é utilizada a técnica de sacos de aniagem emendados, pela facilidade de se encontrar o material nas diferentes regiões e preparo da "tela". Segundo Einloft et al (1997), o uso de técnica de revegetação com sacos de aniagem permite um rápido e abundante recobrimento vegetal no talude, favorecendo a colonização pela fauna microbiana do solo e o estabelecimento de outras plantas.

As telas naturais são de fácil aplicação, pois vêm em forma de rolos e são lançadas como um tapete sobre as encostas. Apresentam como principais vantagens sua característica biodegradável e a promoção de uma excelente contenção de taludes, e como desvantagem: o custo por unidade de área.

\subsubsection{Aplicação de organismos e microrganismos}

No processo de recuperação de áreas degradadas, o componente solo deve ser tratado observando seus aspectos físicos, 
químicos e biológicos. Do ponto de vista biológico, a fauna microbiana do solo exerce forte interação, através dos processos de decomposição da matéria orgânica e liberação de nutrientes, com outros componentes do ecossistema, contribuindo para sua estabilidade. Segundo Campello (1996), o manejo das associações simbióticas pode melhorar de forma considerável o desempenho silvicultural e econômico de diversos plantios florestais, isto se aplica também, em recuperação de áreas degradadas, reduzindo os custos relativos à fertilização.

A utilização de organismos e microrganismos na recuperação está sempre associada à utilização de outros métodos biológicos ou mecânicos. Como principais benefícios da aplicação deste método, citamos: melhoria na absorção de nutrientes, aumento da taxa de absorção de água, aumento da resistência ao ataque de patógenos, melhoria das propriedades do solo, aumentando a fertilidade, melhorando a solubilidade e a reciclagem de nutrientes.

No caso de inoculação de leguminosas, a escolha correta da estirpe de rizóbio é de fundamental importância, visto que já na fase de produção de mudas, as plântulas já respondem positivamente à inoculação.

Outro grupo de microrganismos de grande importância são as micorrizas, associações formadas entre alguns tipos de fungos e raízes de algumas espécies vegetais. As micorrizas atuam como extensões do sistema radicular aumentando a área de contato e a capacidade das raízes absorverem nutrientes. Estes microrganismos se destacam por sua capacidade de absorver íons de baixa mobilidade no solo, melhorando significativamente a absorção de fósforo pelas plantas. Os fungos micorrízicos são responsáveis pela interação entre planta e solo, e podem ser inoculados de diferentes formas, destacando-se a inoculação através de terriço e esporocarpos.

Portanto, a utilização de microrganismos seja na inoculação de mudas nos viveiros, seja diretamente nos locais degradados pode constituir um meio eficiente no auxílio à recuperação de áreas.

\subsubsection{Colocação de poleiros artificiais}

A colocação de poleiros artificiais oferece ponto de pouso para aves que, ao permanecerem nestes locais, defecam, trazendo sementes de espécies provenientes de outras áreas florestais. Em 
trabalho realizado, com o objetivo de analisar a influência de poleiros artificiais na dispersão de sementes (MELO, 1997), na região de Curvelo/ MG, área de cerrado, foi demonstrado que ocorreram mais sementes nos poleiros que nas áreas sem poleiros, e o efeito da distância da fonte de sementes é muito grande neste método.

Este método apresenta algumas vantagens, quando próximo a fontes naturais de sementes, mas deve ser analisado cuidadosamente, pois o plantio de mudas de árvores funciona como poleiros vivos, podendo produzir frutos, atraindo ainda mais as aves para a área e maximizando a velocidade e a diversidade da recuperação.

\subsection{Desenho de sistemas florestais de uso múltiplo}

Sistemas florestais de uso múltiplo são modelos de recuperação ambiental de áreas degradadas onde contemplamos, além dos aspectos ambientais, as funções sociais e econômicas da futura floresta a ser formada. A aplicação de sistemas florestais de uso múltiplo para recuperação ambiental tem uma grande aplicabilidade. Considerando aspectos socioeconômicos e ambientais, envolvidos na recuperação de áreas degradadas, este tipo de modelo tende a ser de grande finalidade em programas a serem desenvolvidos em área de floresta atlântica. $\mathrm{O}$ estímulo econômico, conciliado a aspectos sociais e ambientais e ao atendimento de aspectos legais, torna os modelos de uso múltiplo promissores para serem adotados por órgãos públicos em programas de fomento e por empresas em programas de recuperação. Em ecossistemas florestais bem manejados, são perfeitamente compatíveis atividades de produção florestal e a conservação ambiental. Estes modelos são adequados para áreas onde queremos recuperar a floresta e conciliar atividades produtivas à futura floresta em recuperação.

Na recuperação ambiental, utilizando modelos de sistemas florestais de uso múltiplo, procuramos conciliar a obtenção de benefícios ambientais (conservação do solo, da fauna, flora e água) com a produção de benefícios econômicos (coleta de produtos florestais madeireiros e não madeireiros). A equação para desenho de um modelo ideal deve considerar, em primeiro lugar, o ecossistema original da região e seu processo sucessional, entretanto também são incorporadas variáveis socioeconômico-ecológicos que permitam custear a recuperação em longo prazo e garantir a sustentabilidade do sistema. 
Sistemas florestais de uso múltiplo se distinguem dos sistemas agroflorestais (SAF's), por possuírem somente o componente arbóreo e terem como objetivo principal os aspectos ambientais, isto é, conciliar a rentabilidade econômica com a proteção ambiental, não possuindo componentes agrícolas e animal (doméstico). É um sistema de uso menos intensivo que os SAF's, se aplicado melhor em propriedades médias e grandes, com grande vantagem de poder ser investido em áreas de reservas. No desenho de sistemas florestais, é necessário conhecer profundamente o funcionamento do ecossistema florestal original da região, que fornecerá toda base teórico-científica de informações para o desenvolvimento de modelos de uso múltiplo. A floresta atlântica tropical úmida com toda sua diversidade, complexidade e dinamismo é a base do conhecimento para o desenho destes sistemas. Portanto, em sistemas florestais na recuperação ambiental de áreas de floresta atlântica, devemos considerar como grande aliado à biodiversidade deste ecossistema, o que nos dá grande plasticidade no desenvolvimento de modelos e, consequente, capacidade de adaptação em diversas situações de degradação. A grande diversidade pode resultar em dificuldade de manejo, porém, nos modelos de uso múltiplo, somente algumas espécies são incorporadas ao componente produtivo (menor número de espécies, maior facilidade de manejo).

O conhecimento do processo de sucessão natural - mencionado no capítulo 5 - é de conhecimento indispensável no planejamento de modelos de recuperação ambiental e torna-se mais importante quando anexamos variáveis sociais e econômicas ao processo de planejamento. A mãe natureza é nossa grande professora e a observação dos laboratórios naturais - áreas degradadas e florestas em diferentes estágios sucessionais - são importantes, porém conhecimentos sobre a dinâmica de funcionamento de diferentes ecossistemas, armazenados em estudos, realizados por institutos de pesquisas e universidades, nunca deverão ser desprezados.

\subsubsection{Seleção de espécies}

Além de todos os critérios para seleção de espécies discutido no capítulo 7, especificamente no caso de sistemas florestais de uso múltiplo, devemos incorporar critérios especiais, considerando principalmente espécies de importância econômica. Grupos 
de plantas de importância econômica, pertencentes à flora regional - plantas medicinais, ornamentais, produtoras de alimentos, fibras e outras -, merecem destaque especial nestes modelos, pois eles vão fazer parte do componente econômico do sistema, responsável por sua sustentabilidade (custeio de operações de implantação e manutenção do sistema). Para análise imediata, é interessante trabalharmos com espécies que tenham um mercado conhecido, cuja série histórica de preços do produto seja possível de ser levantada e analisada. Todo trabalho de desenvolvimento de modelos é dinâmico e contínuo, portanto a pesquisa de novos produtos florestais deve ser constante, melhorando sempre o componente socioeconômico dos sistemas florestais de recuperação a serem implantados, potencializando a capacidade de sustentabilidade do sistema. Apesar da redução significativa da área de floresta atlântica, este bioma abriga ainda uma rica biodiversidade.

\subsubsection{Modelagem}

No desenho destes modelos de recuperação (sistemas florestais), é necessária grande habilidade do planejador, que deve buscar conciliar o melhor uso dos recursos disponíveis (luz, água, nutrientes, espaço físico, energia, mão de obra e capital), propiciando, além da recuperação ambiental da área degradada, a melhoria da renda líquida por área, aperfeiçoamento da qualidade do site e de vida dos proprietários. Esta visão holística é necessária para a condução dos trabalhos desde a fase de diagnóstico da região até a implantação dos modelos em escala comercial, devendo existir uma constante reavaliação e reajuste dos modelos. Observa-se que, quanto maior a quantidade de espécies inseridas no componente econômico do modelo, mais complexo fica seu manejo nas fases de estabelecimento e coleta, também fica mais complexa sua avaliação, tanto econômica como social e ambiental. No desenho de modelos de uso múltiplo, devemos buscar um equilíbrio entre número de espécies "econômicas" utilizadas e facilidade de manejo.

Após a escolha das espécies a serem utilizadas, deve ser definido sua distribuição espacial e densidade de plantio nos diferentes ambientes presentes na área a ser recuperada.

É muito importante, na fase de análise econômica, a realização de análises individuais das diferentes espécies que compõem 
a parte econômica do sistema, classificando-as conforme sua importância dentro do sistema. Estas análises permitem definir um número ideal de espécies econômicas (produtos) dentro do sistema, dentro de um limite, quando é possível realizar um "bom manejo" florestal.

As espécies de importância econômica, que vão ser utilizadas nestes modelos, devem ser introduzidas de forma a facilitar a operação de coleta de produtos, o ideal, na maioria dos casos, é o plantio em linhas, construído dentro da floresta que está sendo formada. Nestas linhas, desenhadas em espaçamentos predeterminados, as mudas plantadas podem ser mais bem manejadas, facilitando também a operação de coleta.

Citamos como vantagens dos sistemas florestais de uso múltiplo:

a. benefícios sociais, já que temos necessidade constante da mão de obra, após ativação do sistema - início da fase produtiva;

b. possibilidade de coleta de produtos conforme programação do agricultor - poupança verde - podendo aguardar época de "sobra" de mão de obra na propriedade ou região;

c. maior diversidade, maior equilíbrio, maior aproximação do ecossistema original, quando comparado com sistemas agroflorestais;

d. é possível de se estabelecer um manejo padrão (pacote) de fácil compreensão por parte dos executores (rotina de trabalho);

e. possibilidade permanente de ajustes e introdução de novas plantas produtivas do ponto de vista econômico;

f. possibilidade de utilização de culturas agrícolas no início da implantação, barateando custos iniciais de implantação;

g. podem ser aplicados, em áreas de reserva legal, com pequenas adaptações na fase de desenho e modelagem, moldam-se às características legais regionais (estaduais).

Como exemplo de ilustração de sistemas florestais de uso múltiplo, mostramos, na figura 4, o perfil de um sistema florestal de 
uso múltiplo, desenhado para recuperação de áreas ciliares e florestas de encosta, no extremo sul da Bahia. Este modelo foi desenvolvido pelo autor, juntamente com mais outros quatro modelos, para recuperação ambiental de áreas de florestas ripárias e de encostas, situadas dentro dos projetos de reflorestamento com eucalipto da Veracel Celulose S.A. O modelo mostrado possui como característica a utilização exclusiva de espécies da floresta atlântica regional e, dentro do componente econômico dos sistemas, estão previstos somente com produtos não madeireiros.

A utilização de sistemas florestais tem grande importância na conservação dos demais recursos naturais, pois o ecossistema florestal consiste, principalmente, em áreas tropicais, na vegetação que melhor protege o solo contra a ação erosiva e mantém recursos hídricos em qualidade e quantidade suficientes, fornecendo também abrigo e alimento para a fauna silvestre. Este sistema, se bem manejado, pode conciliar a função protetora ambiental com o manejo sustentável e a coleta de produtos florestais (nem sempre isto significa madeira), contudo, no projeto de desenvolvimento de sistemas florestais, é necessário incorporar conceitos e conhecimentos de autoecologia das espécies, da sucessão florestal e da dinâmica dos fragmentos florestais.

FOTO 13 - Modelo de recuperação ambiental com uso múltiplo, plantio de palmeiras piaçavas, produtoras de fibras, plantio em linhas. Área experimental da Veracel Celulose. Eunápolis, Bahia

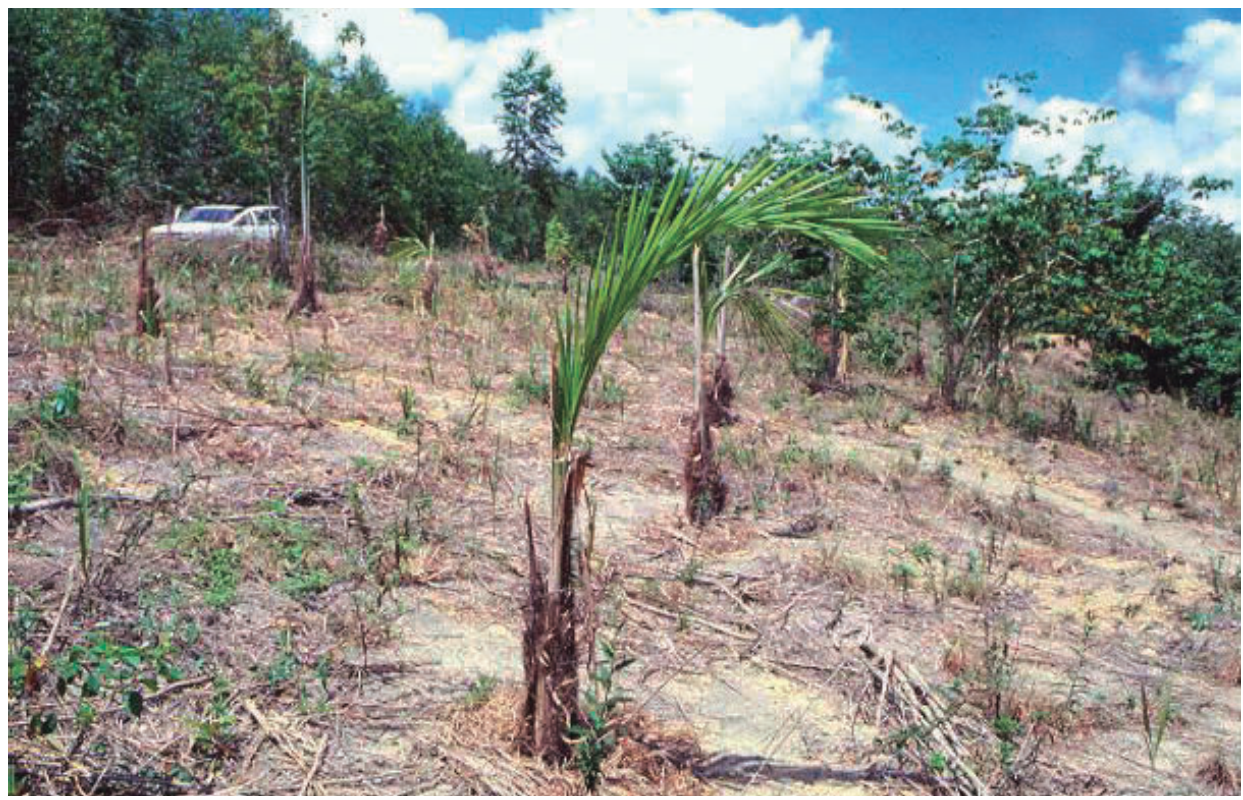


FIGURA 4 - Modelo de sistema florestal de uso múltiplo, utilizando somente plantas da floresta atlântica regional (componente econômico com piaçava e palmito), desenvolvido pelo autor para recuperação de matas ciliares e de encosta, localizadas dentro dos cultivos de eucalipto da Veracel Celulose S.A.. Extremo sul da Bahia

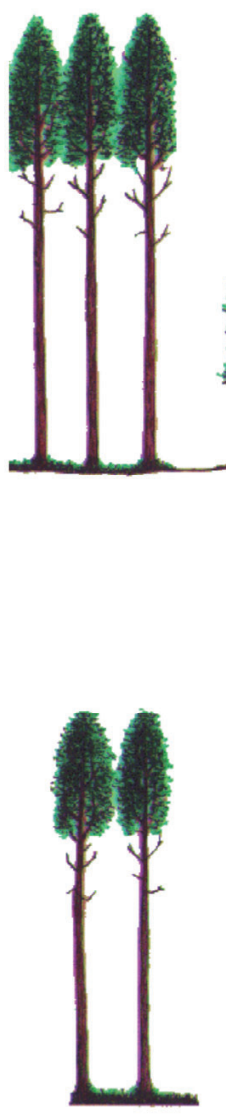

PLANTIO GOMERGIAL

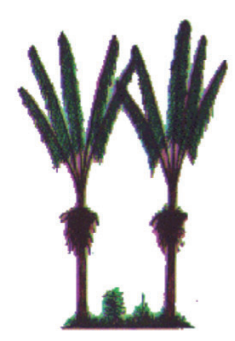

PIAQAVA

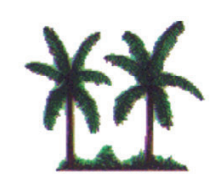

PALMITO (JUÇARA)

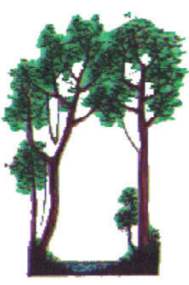

MATA CILIAR

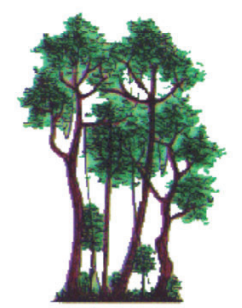

FLORESTA RECUPERADA

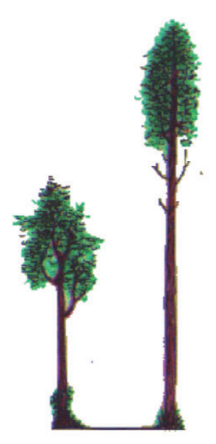

ACEIRO 


\subsection{Modelos de enriquecimento de fragmentos florestais}

Hoje, os fragmentos florestais, em sua maioria, se encontram degradados, devido ao isolamento, extrativismo (vegetal e animal) passado e ausência de dispersores de sementes. Estes fragmentos possuem muitas espécies raras e muitas outras espécies desapareceram da área pelo extrativismo (espécies madeireiras, por exemplo). Estes modelos de enriquecimento são utilizados para aumentar a diversidade de fragmentos florestais, propiciando a retomada do processo de sucessão natural da área, que, na maioria das vezes, se encontra estagnada.

Normalmente, este modelo é aplicado em fragmentos florestais de florestas secundárias, em fragmentos florestais em estágio inicial e médio de regeneração de Mata Atlântica que possuem pequena diversidade de espécies. É um método bom para matas secundárias jovens e com pouca diversidade de espécies (geralmente presente em fragmentos florestais isolados). O enriquecimento pode ser implantado de três distintas maneiras:

\section{Plantio em Faixas}

O plantio em faixas é realizado dentro das áreas dos fragmentos florestais, e a distância entre as linhas deve ser aberta em distância variável, conforme estado de conservação e necessidade de intervenção na área. Segundo Galvão e Medeiros (2002), as faixas devem possuir 1 metro de largura, atravessando a área, a intervalos de 3-10 metros de distância e, dentro da mesma faixa, deverão ser abertas covas distanciadas de 2 a 5 metros entre elas.

Considerando que vamos ter um ambiente mais sombreado, as espécies a serem plantadas devem pertencer a grupos ecofisiológicos de estágios mais avançados de sucessão, preferencialmente secundárias tardias e clímax. Devemos observar os dispersores de sementes das espécies que vão ser utilizadas.

Este método pode ser modelado como um sistema de uso múltiplo com a introdução de espécies madeireiras nobres nativas nas linhas, o que facilita o manejo futuro das espécies introduzidas.

\section{Ilhas/Clareiras}

Neste sistema, o plantio é feito de maneira aleatória, buscando as grandes clareiras existentes dentro da área florestal formando 
ilhas, isto é, pequenos maciços em clareiras naturais com alta diversidade. Dependendo do tamanho da clareira, podemos plantar espécies pioneiras, secundárias iniciais, secundárias tardias e clímax. Em pequenas clareiras, devem ser priorizadas as espécies secundárias tardias ou clímax.

\section{Controle de cipós}

Em fragmentos florestais pequenos e isolados, é comum a presença de grande infestação de cipós. Esta infestação prejudica muito a regeneração natural de espécies arbóreas e o prosseguimento do processo de sucessão florestal, necessitando da prática de manejo florestal denominada controle de cipós. Considerando que estes cipós também possuem grande importância ambiental (fornecendo floração e frutificação em períodos variáveis), não é recomendável a eliminação de $100 \%$ dos cipós, mas sim somente o controle deste grupo de espécies.

\subsection{Avaliação dos modelos de recuperação ambiental}

Com objetivo de analisar e conhecer o desempenho e a aplicabilidade dos modelos propostos, são necessárias realizações de diferentes avaliações, contemplando especialmente os aspectos ambientais, sociais, econômicos e legais. Um dos grandes erros apresentados em trabalhos, na área de recuperação ambiental de floresta atlântica, é o de não se fazer uma análise holística dos modelos desenhados, considerando custos e simulando seu desempenho futuro.

No caso de recuperação ambiental, as avaliações referentes aos aspectos ecológicos são as mais importantes, pois o objetivo principal é a recomposição do ecossistema original. Os aspectos econômicos são também muito importantes, não só na consideração do custo da recuperação, mas também, na geração de receitas, como no caso dos sistemas florestais de uso múltiplo. A análise do desempenho social dos modelos é importante para agregar mais valores aos sistemas propostos, considerando a grande importância do componente social no conceito moderno de meio ambiente. Já o conhecimento da legislação em diferentes níveis - municipal, estadual e federal - é fundamental para adequarmos os modelos a estes parâmetros, e obtermos futuros certificados e selos verdes. 


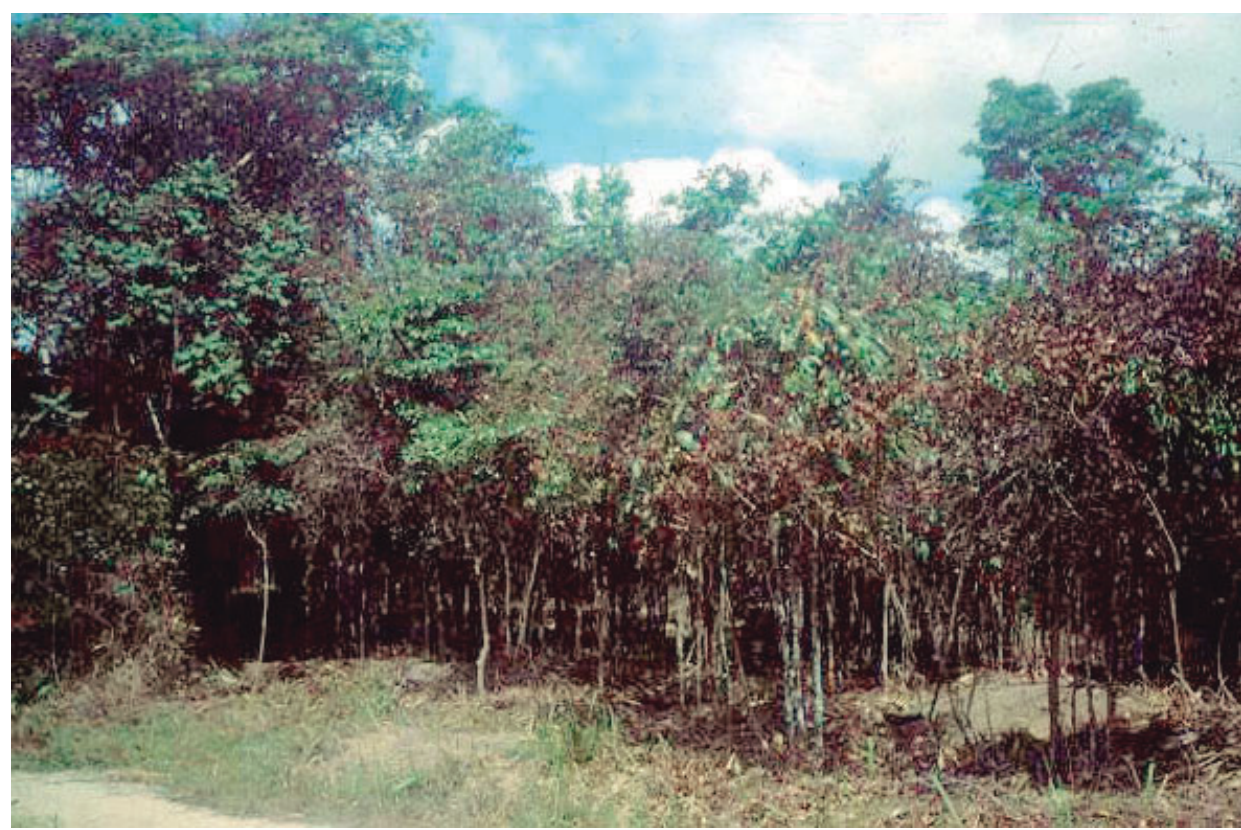

FOTO 14 - Fragmento florestal em estágio inicial de regeneração, esta área possuía grande infestação de cipós o que impedia o desenvolvimento do processo sucessional. Neste fragmento florestal foi realizado a prática de controle de cipós

\subsubsection{Avaliação ambiental}

As avaliações ambientais devem se embasar em fatores mensuráveis. Um sistema, que pode ser utilizado, é o de classificar os critérios ambientais em diferentes pesos e dar notas específicas para cada um.

Para ilustrar citamos, como exemplo, algumas características ambientais possíveis de serem mensuradas:

a. conservação de solo (em função da densidade do plantio);

b. conservação da água (monitoramento da qualidade da água antes e depois do plantio);

c. conservação de biodiversidade (baseado no número de espécies nativas utilizadas, originárias do ecossistema original que está sendo recuperado);

d. avaliação da regeneração natural (diversidade vegetal que surge após o plantio);

e. atrativo da fauna silvestre (número de espécies atrativas de fauna utilizadas). 
Estas características podem ter diferentes pesos $(1,2,3)$ e avaliadas em notas, alocando diferentes pontuações como:

1. ótimo: 10

2. bom: $8-9$

3. satisfatório: $6-7$

4. ruim/reprovado: $<6$

Finalmente, podemos construir uma tabela combinando características ambientais, pesos e notas, sendo possível comparar o desempenho ambiental dos diferentes modelos desenhados e definir os melhores do ponto de vista ambiental, dando prioridade para atingir os objetivos propostos inicialmente no projeto.

\subsubsection{Componente econômico}

Na área de domínio floresta atlântica, existe uma grande carência de informações sobre parâmetros econômicos de recuperação ambiental. O custo de recuperação pode, muitas vezes, significar um obstáculo e desestímulo para a realização de trabalhos nesta linha.

Quando falamos em modelos de uso múltiplo, em que temos também a produção econômica incorporada ao processo de recuperação, maior é a necessidade de detalhar o conhecimento do componente econômico do sistema. Sugerimos fazer uma análise econômica, enfocando vários parâmetros, para termos maior segurança na tomada de decisão, para isto, faz-se necessário incluir na equipe de planejamento um profissional da área econômica. Citamos abaixo alguns itens que devem ser considerados em uma avaliação econômica:

a. Custo total - implantação e manutenções: incluem gastos com preparo do terreno, coveamento, adubação, plantio, insumos (mudas e fertilizantes) e operações de manutenção. O profissional que trabalha nesta área deve possuir boas planilhas de custos e rendimentos de operações de recuperação. Observamos que, na faixa de floresta atlântica, existe uma variação regional muito grande, portanto estas tabelas de rendimentos e custos de mão de obra não devem ser generalizadas para todas as regiões. 
b. Tempo de carência - em sistemas florestais implantados em áreas degradadas, devemos considerar o tempo necessário até a ativação do componente econômico. Em geral, os produtos florestais não madeireiros, na região da floresta atlântica, possuem um período de tempo até iniciar sua produção, temos como exemplo o palmito juçara, que demora em torno de oito anos para início da produção.

c. Lucro bruto (R $\$ / \mathrm{ha} / \mathrm{ano})$ - é o total de receitas obtidas a partir da ativação total da produção do sistema, essa análise econômica deve ser feita em planilhas nos componentes que são incorporados ao sistema produtivo ao longo dos anos. Em função do modelo de recuperação a ser adotado, este custo de implantação pode variar entre $\mathrm{R} \$ 0,60$ a $\mathrm{R} \$ 2,00$ por muda plantada, para o sistema tradicional de plantio de mudas de espécies arbóreas, baseado em dados de Jesus (1994), Piña-Rodrigues et al (1997) e Almeida (1997).

d. Taxa interna de retorno (TIR) - para o cálculo da TIR, são utilizadas taxas de custo de capital. Os parâmetros utilizados objetivam avaliar o projeto da forma mais realista possível.

É importante ressaltar que, como qualquer projeto agrícola, a recuperação ambiental é influenciada por intempéries climáticas, de difícil previsão, portanto se aconselha que o projeto seja aceito somente se o resultado da TIR tiver sido bastante superior ao custo de capital, cobrindo os riscos do sistema. Porém devemos considerar que o objetivo principal dos sistemas é promover a recuperação ambiental e não, exclusivamente, obter lucros, fazendo muitas vezes com que a análise seja feita de forma mais abrangente, não se exigindo uma TIR tão superior ao custo de capital.

e. Valor presente líquido (VPL) - permite fazer comparações entre diferentes opções de modelos, considerando a mesma taxa de desconto, deve-se aceitar o projeto que tiver o maior VPL.

Vale lembrar que, nem sempre, o projeto com o maior VPL é o que possui a maior TIR. Deve-se, portanto 
fazer uma avaliação concomitante entre as duas formas de análise de investimento. Normalmente, os projetos devem ser aceitos se forem viáveis economicamente nas duas análises, ou se fazer uma média ponderada dos resultados obtidos comparando-se as diversas possibilidades de investimento.

Informações referentes à produtividade por área, mercado consumidor devem ser as mais confiáveis possíveis e atualizadas, sendo obtidas junto a institutos de pesquisas ou através de levantamentos realizados na região.

\subsubsection{Desempenho social}

O desempenho social pode ser mensurado através de vários parâmetros como capacidade de geração de empregos, salários e benefícios, qualidade de vida e outros.

Em modelos de recuperação ambiental de uso múltiplo, podemos observar um grande potencial de geração de empregos permanentes. $\mathrm{O}$ número de empregos gerados nas fases de implantação e manutenção, assim como aqueles gerados na fase de colheita, deve ser baseado em rendimentos operacionais médios praticados na região do projeto.

Neste item, devemos fazer projeções da capacidade de geração de empregos, ao longo de horizonte de tempo, principalmente para sistemas de uso múltiplo, nos quais temos a incorporação parcelada de novos produtos e consequente geração gradativa de novas oportunidades de trabalho.

O sistema de organização da mão de obra nas diferentes etapas, desde a implantação até a colheita, também deve ser bem conhecido: empreiteiro-prestador de serviços, microempresas responsáveis por determinadas áreas, cooperativa, associação de coletores ou funcionários da empresa empreendedora. Serviços de beneficiamento e industrialização de produtos, oriundos dos sistemas florestais de uso múltiplo, podem maximizar os benefícios sociais.

\subsubsection{Aspectos legais}

Já foram discutidos, no capítulo 3, os aspectos legais ligados à recuperação ambiental. Na fase de avaliação, é interessante 
termos uma ideia espacial - zoneamento - das diferentes áreas especiais citadas na legislação. É importante saber se estamos dentro, vizinhos ou próximos a alguma unidade de conservação (pública ou particular), e se a área é de preservação permanente, reserva legal ou se encaixa em outra categoria de conservação. Principalmente, quando os objetivos da recuperação não envolvem somente recuperação ambiental, como no caso dos modelos de uso múltiplo, esta análise deve ser rigorosa, estudando as possíveis limitações legais após a ativação do sistema florestal e início da coleta de produtos.

A legislação deve ser conhecida em diferentes níveis, desde o âmbito municipal até o federal. Por exemplo, atualmente em alguns estados brasileiros não é possível a coleta seletiva de madeira nas áreas de reserva legal, em outros é possível realizar esta retirada de maneira sustentável. 